\title{
Towards Evidence-based Water Management in the Murray Darling Basin, Australia
}

\author{
Neil Saintilan
}

Received: 10 January 2012 / Accepted: 1 February 2012 /Published online: 14 February 2012

(C) Society of Wetland Scientists 2012

\begin{abstract}
The paper introduces a Special Feature of Wetlands concerned with the ecology and management of the Murray Darling Basin, Australia. The Murray and Darling River systems in SE Australia combine to form the largest draining basin on the continent and the most economically important. The river system supports 16 wetlands listed as internationally important under the Ramsar convention, and sustains nationally significant populations of waterbirds, and endemic flora and fauna. Many of these values have been threatened by the development of water resources, particularly in the southern tributaries, and the diversion of water for irrigated agriculture. The restoration of ecological health within the Murray Darling is contingent on the optimal use of water reserved for environmental use. This objective can only be achieved through the development and application of quantitative, testable models linking environmental water regimes to ecological outcomes. This Special Feature of Wetlands explores the use of evidence in support of environmental water management, with papers considering the standards of evidence, the testing of assumptions relating to indicator species, the formulation of empirically-based flow-response models and the incorporation of these relationships in decision support tools. The further testing and development of quantitative predictive models is advocated as a key objective of environmental flow monitoring.
\end{abstract}

Keywords Adaptive management - Murray Darling Basin . Environmental flow $\cdot$ Planning

N. Saintilan $(\bowtie)$

Rivers and Wetlands Unit, Department of Premier and Cabinet, Office of Environment and Heritage NSW,

PO Box A290, Sydney South, NSW 1232, Australia

e-mail: neil.saintilan@environment.nsw.gov.au

\section{Introduction}

This Special Feature of Wetlands draws together papers from a range of scientific disciplines around a common theme of water and wetland ecology in the Murray Darling Basin, and the standards of evidence required by adaptive, empiricallybased management. The River Murray, and its tributary the Darling, combine to form Australia's largest river system, covering an area of over 1000000 square kilometres, oneseventh of the continental land mass. Though rising from humid subtropical and temperate climates in its eastern headwaters, much of the basin is situated in semi-arid lowlands where rivers traverse gently sloping floodplains. The meandering and anastomosing of river channels in deltaic lowlands of the Murray-Darling has given rise to over 30000 wetlands, 16 of which have been listed as internationally important under the Ramsar Convention. The basin supports several of the most important waterbird rookeries on the continent (Saintilan and Overton 2010).

The Murray Darling basin is also home to 2 million people, and is often described as the agricultural heartland of the nation. The Murray Darling produces $70 \%$ of Australia's irrigated crops, accounting for nearly $40 \%$ of the nation's agricultural production. On the world's driest inhabited continent, competition for water is nowhere more focused than in the Murray Darling, where debate over water allocations between jurisdictions and between commercial, domestic and environmental uses have continued for more than a century.

The management of water in support of the ecological assets of the Murray Darling has been beset historically by the absence of quantitative information on relationships between flow and ecological response. As a result, for much of the period up to the late 1990s environmental water management was 'essentially ad hoc' (Walker et al. 1995) and based on 'best informed guesses' (Thoms et al. 2000). 
The legacy of this lack of informed strategic intent is reflected in a growing body of evidence suggesting that river and wetland health had declined across the basin over recent decades. The most recent report of the Sustainable Rivers Audit, which presents a snap-shot of river health across 23 tributary valleys within the basin, described only one valley as being in good condition, two in moderate condition, seven in poor condition and 13 in very poor condition (MDBC 2008). The effect of water diversion had been exacerbated by protracted drought, to the extent that flows through the river mouth ceased for 40 percent of the time in recent decades, up from 1 percent under natural conditions, with severe ecological consequences in the river estuary (CSIRO 2008).

The declining condition of the aquatic ecosystems of the Murray Darling, and in particular the wetlands of international importance, has prompted action by Federal and State governments. Central to this response has been the passing of the Water Act (Commonwealth of Australia 2007), by which the Federal government has assumed an overarching water planning role. The Water Act 2007 provides the legislative mechanism for the Federal government to manage water in the national interest while giving effect to international treaty obligations (such as those defined under the Ramsar Convention). The Act establishes the Murray Darling Basin Authority, tasked with the development of an overarching water management plan for the basin to which state water management initiatives must conform. In support of this planning process, more than \$US10 billion is being spent on a range of measures seeking to address an imbalance between extractive and environmental uses of water, including the purchase of entitlements to use water, improvements to infrastructure and water use efficiency.

\section{Scientific Evidence in Water Management}

Environmental water refers to that component of river flow reserved to meet the needs of the natural environment. In the long history of water resource development in the MurrayDarling, a growing proportion of water has been allocated for extraction and consumptive use, and in recent years the need to redress the imbalance between economic and environmental water use across the basin has become clear. However, restoring water to the environment following over-allocation to commercial use is an expensive process, both financially and socially. It is appropriate given the size of the investment and the opportunity costs associated with environmental water purchase that the evidence used to determine environmental benefits of water allocation be subject to scrutiny. The nature of evidence in support of environmental water application could equally be taken as a theme for this Special Feature of Wetlands.
The management of environmental water for ecological outcomes has been based in the past on a combination of practical experience, local knowledge and adaptive practice, unsupported by a rigorous, evidence-based predictive framework (Sims et al. 2012, this volume). The call for greater rigor in the use of environmental evidence is taken up by Grove et al. (2012, this volume) and Webb et al (2012, this volume). Causal criteria analysis is a technique borrowed from epidemiology and codified by Norris et al. (2005) into the Eco Evidence framework, as a robust test of the admissibility of evidence in support of ecological hypotheses. The rationale of this approach and its application to date in Murray Darling Basin research is described in the contribution by Webb et al. (2012). Grove et al (2012) apply the technique to evidence proposing a link between environmental flows and floodplain geomorphology, winnowing out the vast majority of studies due to low statistical vigour. The impediment of poor replication limiting experimental design in geomorphology may be overcome to some extent by technological advances in the field of remote sensing that have recently facilitated a dramatic increase in the quantity of data available for geomorphic analyses. For example, Ryder et al. (2012, this volume) demonstrate how high-resolution Lidar and digital imagery can be used in concert to map geomorphic and habitat features in a way that allows systematic testing of hypotheses relating flow to habitat availability.

Sims et al. (2012, this volume) take a fresh look at the spatial patterns of hydrological modification across the Murray-Darling, using a multivariate cluster analysis to classify floodplains using a range of flow modification metrics. The large rivers of the southern basin (the Murray, the Murrumbidgee and the Lachlan) have been heavily impacted after a long period of water resource development, both hydrologically and ecologically. However, the authors warn that terminal floodplain wetlands elsewhere in the basin are highly susceptible to minor alterations in flow conditions. The study provides a quantitative basis for the setting of flow objectives in aquatic restoration programs.

Environmental water planning and management has frequently used vegetation habitats as surrogates for the water requirements of the broader suite of species found therein. In a recent review of the scientific basis of the proposed Murray Darling Basin Plan, Young et al. (2011) point to the need for further testing of this assumption. In this volume, Rogers et al. (2012) provide the first comprehensive test of the "representative species" model widely used in the basin, and find that the common vegetation units generally require less frequent and lower duration flooding than many of the bird and amphibian species that co-exist on the floodplain. Clearly, we need to rethink the adage that in looking after the floodplain vegetation we are catering for the needs of the biota they support.

Given the importance of the Murray Darling basin in supporting waterbird populations at a continental scale, the 
volumes of water required to initiate and sustain successful breeding events is foundational information required for water planning. Rogers et al (2012) demonstrate that the water demand of vegetated habitats is not of itself sufficient to accommodate this important ecological function. Arthur et al. (2012 this volume) provide the type of empirical analysis required for estimates of flow thresholds required for breeding success. The study suggests that while generalisations can be made, thresholds of flooding duration and seasonality may differ between locations. There is clearly an ongoing role for monitoring in testing and refining quantitative models linking waterbird breeding success with flow metrics.

The shift from qualitative to quantitative models of species responses to flow has been facilitated by the development of Decision Support Systems. The application of integrative predictive models began in the Murray Darling with the Murray Flow Assessment Tool (Young et al. 2003) which sought to integrate ecological and hydrological models required to optimise the delivery of environmental water. More recently, valley-specific tools have been developed for the Lower Murrumbidgee and the "IBIS" tools developed for the Narran, Gwydir and Macquarie valleys in the north of the basin (Merritt et al. 2010; Alexander et al. 2009).

Decision Support System developers have found Baysean networks to be a useful way of dealing with the uncertainty inherent in ecological prediction (Merritt et al. 2010). Baysean networks attach probabilities to qualitative models linking ecological states to multiple causes or drivers. Gawne et al. (2012, this volume) describe the development of a baysian belief network to guide the management of environmental flows to wetlands in support of native fish. They developed models specific to four species, three native and one introduced (the common carp). Carp (Cyprinus carpio) are known to take advantage of environmental flows to breed in large numbers in floodplain wetlands (Stuart and Jones 2006). Mazumder et al. (2012 this volume) demonstrate using stable isotope analysis the flexibility of juvenile carp in shifting their diet as hydrological conditions change on the floodplain, and their capacity to compete with native fish species over common food items as the floodplain wetlands dry. Gawne et al. (2012) apply their Baysean network in a case study to show that maintaining residual pools was the best option for the maintenance of the native species (Australian smelt) in spite of the opportunities provided for the common carp.

\section{Conclusions}

The recent intervention by Federal and State governments to arrest the decline in ecological condition of the Murray Darling Basin has provided impetus to the development of improved hydrological and ecological response models specific to rivers and wetlands within the basin. The development of these models and their application in water planning has exposed many deficiencies in data and system understanding. Significant amongst these include:

- an incomplete inventory of wetlands within the basin and their flood dependency, preventing basin-wide prioritorisation and optimisation in environmental water delivery

- a lack of gauging information in critical wetlands, preventing the calibration and improvement of hydrological models at important nodes

- a paucity of quantitative studies relating flow and ecological condition for many important species of aquatic biota,

- a poor understanding of the trophic and competitive interactions between biota occupying rivers and floodplain wetlands, and their importance to overall ecosystem health and resilience

- limited understanding of the vulnerability of biota to climatic variability and and climate change

The above-listed model deficiencies should provide a focus for monitoring and research programs within the Murray Darling. Nichols and Williams (2006) have argued for a close link between monitoring and the specific intention of management interventions. In the case of the Murray Darling, environmental flows are delivered on the assumption of specific hydrological and ecological outcomes being attained, at the scale of the individual flow and the flow regime. Ideally, these assumptions should be made explicit, as the outputs of hydrological and ecological response models. Post-event monitoring provides an opportunity to test model assumptions against ecological and hydrological data (Saintilan and Imgraben 2012). In this way, each environmental flow becomes an opportunity to test and refine predictive models that in turn are used as the basis for long-term water planning. This iterative, or 'adaptive management' process will, if properly resourced and supported, overcome many of the impediments that have led to poor environmental outcomes and suboptimal use of water in the past.

Acknowledgements The papers in this Special Section were written following a meeting funded by the National Water Commission, the Murray Darling Basin Authority, CSIRO Land and Water and the NSW Office of Environment and Heritage.

\section{References}

Alexander B, Ling J, Saintilan N (2009) Investigations to better the use of environmental water in the northern Murray Darling Basin, Australia- Subprogram II of the NSW Rivers Environmental Restoration Program. Wetland Science and Practice 26(4):6-11

Arthur A, Reid J, Kingsford R, McGinness H, Ward K, Harper M (2012) Breeding thresholds of colonial breeding waterbirds in the Murray-Darling Basin. Australia, Wetlands (this volume)

Commonwealth of Australia (2007) Water Act 2007. Available at http://www.comlaw.gov.au/Details/C2007A00137 
CSIRO (2008) Water availability in the Murray-Darling Basin. Report from the CSIRO to the Australian Government. CSIRO Water for a Healthy County, Canberra

Gawne B, Price A, Koehn JD, King AJ, Nielsen DL, Meredith S, Beesley L, Vilizzi L (2012) A Bayesian belief network decision support tool for watering wetland to maximise native fish outcomes Wetlands (this volume)

Grove J, Webb JA, Marren P, Stewardson MJ, Wealands SR (2012) High and dry: comparing literature review approaches to reveal the data that informs the geomorphic management of regulated river floodplains. Wetlands (this volume)

Mazumder D, Johansen M, Saintilan N, Illes J, Kobayashi T, Knowles L, Wen L (2012) Trophic shifts involving native and exotic fish during hydrological recession in floodplain wetlands. Wetlands (this volume)

MDBC (2008) Murray-Darling Basin Rivers: Ecosystem Health Check, 2004-2007. Sustainable Rivers Audit Report 1. MurrayDarling Basin Commission, Canberra.

Merritt W, Powell S, Pollino C, Jakeman T (2010) IBIS: a decision support system for managers of environmental flows into wetlands. In: Saintilan N, Overton I (eds) Ecosystem response modelling in the Murray Darling Basin. CSIRO Publishing, Melbourne, pp 119-136

Norris RH, Liston P, Mugodo J, Nichols S, Quinn GP, Cottingham P, Metzeling L, Perriss S, Robinson D, Tiller D, Wilson G (2005) Multiple lines and levels of evidence for detecting ecological responses to management intervention. In: Rutherfurd ID, Wiszniewski I, Askey-Doran MJ, Glazik R (eds) Proceedings of the 4th Australian Stream Management Conference: linking rivers to landscapes. Department of Primary Industries, Water and Environment, Launceston, Tasmania, pp 456-463. Available at http://tinyurl.com/ Norris-et-al-2005

Nichols JD, Williams BK (2006) Monitoring for conservation. Trends Ecol Evol 21(12):668-673

Rogers K, Ralph TJ, Saintilan N (2012) Can representative species be used as surrogates for wetland inundation requirements? Wetlands (this volume)
Ryder D, Frazier R, McIntyre E, Stewart M. (2012) Understanding riverine habitat inundation patterns: remost sensing tools and techniques. Wetlands (this volume)

Saintilan N, Imgraben I (2012) Principles for the monitoring, evaluation and reporting of wetland extent and condition in Australia. Environ Monit Assess 184(1):595-606

Saintilan N, Overton I (2010) Lessons learnt from ecosystem response modelling and future directions for the Murray-Darling Basin. In: Saintilan N, Overton I (eds) Ecosystem response modelling in the Murray Darling Basin. CSIRO Publishing, Melbourne, pp 411418

Stuart IG, Jones M (2006) Large, regulated forest floodplain is an ideal recruitment zone for non-native common carp (Cyprinus carpio L.). Mar Freshw Res 57:337-347

Sims NC, Chariton AA, Jin W, Colloff MJ (2012) A classification of floodplains and wetlands of the Murray-Darling Basin based on changes in flows following water resource development. Wetlands (this volume)

Thoms M, Suter P, Roberts J, Koehn J, Jones G, Hillman T, Close A (2000) Report of the River Murray Scientific Panel on Environmental Flows: River Murray-Dartmouth to Wellington and Lower Darling River, Murray-Darling Basin Commission, Canberra

Walker KR, Sheldon F, Puckeridge JT (1995) A perspective on dryland river ecosystems. Regul Rivers: Res Manage 11(1):85-104

Webb JA, Nichols SJ, Norris RH, Stewardson MJ, Wealands SR, Lea P (2012) Ecological response to flow alteration: assessing causal relationships with Eco Evidence. Wetlands (this volume)

Young WJ, Scott AC, Cuddy SM and Rennie BA (2003) Murray flow assessment tool: a technical description. Client Report. CSIRO Land and Water, Canberra

Young WJ, Bond N, Brookes J, Gawne B, Jones GJ (2011) Science Review of the Estimation of and Environmentally Sustainable Level of Take for the Murray Darling Basin. A Report to the Murray Darling Basin Authority from the CSIRO Water for a Healthy Country Flagship. pp 36. 